\title{
Media Power Point Berbasis Pendekatan Kontekstual pada Materi Siklus Air Muatan IPA Sekolah Dasar
}

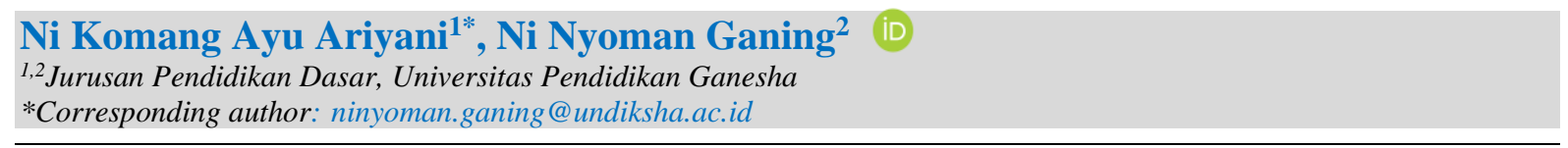

\begin{abstract}
Abstrak
Kurangnya media yang menarik membuat pembelajaran menjadi kurang optimal sehingga siswa mengalami kesulitan dalam memahami materi pembelajaran. Untuk mengoptimalkan proses pembelajaran, perlu dikembangkan media pembelajaran yang sesuai dengan kebutuhan siswa. Penelitian ini bertujuan untuk mengembangkan media Power Point berbasis pendekatan kontekstual pada materi siklus air muatan IPA kelas V Sekolah Dasar. Jenis penelitian ini yaitu menggunakan model pengembangan Hannafin and Peck yang terdiri dari tahap penilaian kebutuhan, tahap desain dan tahap pengembangan dan implementasi. mendeskripsikan validitas media Power Point berbasis pendekatan kontekstual menurut review ahli isi pembelajaran, ahli desain pembelajaran, ahli media pembelajaran, dan uji coba perorangan. Metode pengumpulan data yang digunakan, yaitu: observasi, wawancara, pencatatan dokumen, dan kuesioner. Analisis data menggunakan analisis deskriptif kualitatif dan kuantitatif. Subjek dalam penelitian ini adalah siswa kelas V SD. Dalam pengembangan media Power Point berbasis pendekatan kontekstual ini validitas media berdasarkan penilaian ahli isi pembelajaran sebesar $90,00 \%$ dengan kualifikasi sangat baik, ahli desain pembelajaran sebesar 90,38\% dengan kualifikasi sangat baik, ahli media pembelajaran sebesar 88,33\% dengan kualifikasi baik, dan uji coba perorangan sebesar 92,50\% dengan kualifikasi sangat baik. Dengan demikian dapat disimpulkan bahwa media Power Point berbasis pendekatan kontekstual ini layak digunakan dalam pembelajaran karena dapat menarik minat belajar siswa khususnya pada pembelajaran dalam jaingan dan dapat membantu siswa lebih fokus dalam belajar.
\end{abstract}

Kata kunci: Power point; pendekatan kontekstual; IPA

\section{Abstract}

The lack of interesting media makes learning less than optimal so that students have difficulty understanding the learning material. To optimize the learning process, it is necessary to develop learning media according to the needs of students. This study aims to develop a Power Point media based on a contextual approach to the water cycle material for science class V Elementary School. This type of research is using the Hannafin and Peck development model which consists of a needs assessment stage, a design stage and a development and implementation stage. describe the validity of Power Point media based on contextual approach according to the review of learning content experts, learning design experts, learning media experts, and individual trials. Data collection methods used, namely: observation, interviews, document recording, and questionnaires. Data analysis used descriptive qualitative and quantitative analysis. The subjects in this study were fifth grade elementary school students. In the development of Power Point media based on this contextual approach, the validity of the media based on the assessment of learning content experts is $90.00 \%$ with very good qualifications, $90.38 \%$ learning design experts with very good qualifications, $88.33 \%$ learning media experts with good qualifications, and individual trials of $92.50 \%$ with very good qualifications. Thus, it can be concluded that this contextual approach-based Power Point media is suitable for use in learning because it can attract students' interest in learning, especially in online learning and can help students focus more on learning.

Keywords: Power point; contextual approach; Natural Science

\begin{tabular}{|c|c|c|}
\hline History: & & Publisher: Undiksha Press \\
\hline Received & : 11 April 2021 & Licensed: This work is licensed under \\
\hline Revised & : 20 April 2021 & a Creative Commons Attribution 4.0 License \\
\hline Accepted & : 28 Juni 2021 & cc) (7) () \\
\hline Published & : 25 Juli 2021 & (c) CY SA $_{\text {SA }}$ \\
\hline
\end{tabular}

\section{Pendahuluan}

Perkembangan teknologi informasi yang semakin pesat di era globalisasi saat ini tidak bisa dihindari lagi pengaruhnya terhadap dunia pendidikan (Budiman, 2017; Dewi et al., 2019). Kemajuan ilmu pengetahuan dan teknologi memiliki pengaruh yang sangat besar dalam berbagai bidang kehidupan manusia (Kharisma \& Arvianto, 2019; Kuswanto \& 
Radiansah, 2018). Pendidikan sebagai salah satu bagian yang tidak terpisahkan dari proses pendewasaan manusia tentu di satu sisi memiliki andil yang besar bagi pengembangan ilmu pengetahuan dan teknologi tersebut, namun di sisi lain pendidikan juga perlu memanfaatkan kemajuan ilmu pengetahuan dan teknologi agar mampu mencapai tujuannya secara efektif dan efisien (Muhson, 2010). Untuk meningkatkan kualitas pendidikan diperlukannya media sebagai penunjang dalam proses pembelajaran. Dengan adanya media pembelajaran akan membuat proses pembelajaran lebih menarik, misalnya dari segi tampilan yang dikombinasikan dengan beberapa gambar ataupun animasi (Kuswanto \& Radiansah, 2018).

Permasalahan yang terjadi pada proses pembelajaran khusunya mata pelajaran IPA masih memiliki banyak permasalahan dalam pengembangan medianya. Belum adanya hal-hal baru dalam penemuan konsep IPA siswa dalam belajar dikelas terjadi karena adanya pendekatan pembelajaran yang menetap terhadap proses pembelajaran yang kurang sesuai dengan tujuan pembelajaran IPA (Ariyanto, 2018; Azura et al., 2019). Secara umum, penggunaan media pembelajaran IPA yang kurang maksimal dapat mempengaruhi pelaksanaan suatu pembelajaran. Sejalan dengan berbagai penelitian diatas, berdasarkan hasil pengamatan dan observasi di Sekolah Dasar menemukan bahwa media yang digunakan dalam proses pembelajaran khususnya pada muatan IPA kurang menarik perhatian siswa dan siswa mudah merasa bosan saat pembelajaran berlangsung. Dari hasil wawancara, guru mengalami kendala dalam membuat media yang menarik untuk digunakan dalam proses pembelajaran. Guru belum pernah menggunakan media Power Point sebagai alat bantu dalam mengajar. Hal ini menyebabkan rendahnya prestasi belajar IPA siswa kelas VA SD Negeri 1 Baturiti. Oleh karena itu, pembuatan media pada muatan IPA sangat penting untuk dilakukan agar siswa dapat lebih memahami materi yang menyangkut benda-benda alam yang ada di lingkungan sekitar.

Media pembelajaran adalah segala sesuatu yang dapat dipergunakan untuk menyalurkan pesan, merangsang pikiran, perasaan, perhatian, dan kemauan siswa, sehingga dapat terdorong terlibat dalam proses pembelajaran (Christopher et al., 2019; Pakpahan \& Fitriani, 2020; Suwasono, 2013). Media sebagai salah satu komponen dalam sistem itu, mempunyai fungsi sebagai sarana komunikasi non-verbal(Ulya \& Irawati, 2016). Sebagai salah satu komponen sistem, berarti media mutlak harus ada atau harus dimanfaatkan di dalam setiap pembelajaran. Adanya media pembelajaran dalam penyampaian materi di dalam kelas akan menambah minat siswa dalam belajar (Irfan et al., 2019; Supriyono, 2018). Penerapan media audio visual pada pembelajaran dinilai sangat optimal karena dapat meningkatkan motivasi dan minat belajar mahasiswa serta dapat memperjelas materi yang disampaikan (Busyaeri et al., 2016; Sholiha, 2017; Yusup et al., 2016). Salah satu media yang dapat digunakan dalam pembelajaran adalah media Power Point. Microsoft Power Point merupakan program aplikasi software yang dapat digunakan untuk menyampaikan materi berupa tulisan, gambar bentuk, foto, aneka warna dan jenis tulisan, fitur hyperlink, audio, video, dan animasi (Nurhidayati et al., 2019; Seruni et al., 2019). Power Point dalam pembelajaran dapat diartikan sebagai aplikasi multimedia yang digunakan dalam proses pembelajran, dengan kata lain untuk menyalurkan pesan (pengetahuan, keterampilan dan sikap) serta dapat merangsang pikiran, perasaan, perhatian dan kemauan belajar sehingga secara sengaja proses belajar terjadi, bertujuan dan terkendali (Iswanto et al., 2018; Kurniati \& Perdana, 2018).

Temuan penelitian sebelumnya menunjukkan secara ilmiah bahwa media Power Point IPA untuk siswa kelas IV SD Negeri Samirono dapat meningkatkan ketertarikan siswa pada media pembelajaran (Wijayanti \& Christian Relmasira, 2019). Selain itu, penggunaan media pembelajaran IPA berbasis Power Point dapat menarik perhatian dan motivasi siswa dalam menerima pembelajaran (Irfan et al., 2019). Dalam pengembangan media Power Point berbasis sparkol pada pokok bahasan Perumusan Dasar Negara pada mata pelajaran PKN 
terbukti sangat valid dan efektif dipergunakan dalam proses pembelajaran (Sunarni, 2016). Penelitian tentang pengembangan media pembelajaran multi media Power Point pada mata kuliah sejarah Asia Timur menunjukkan hasil yang sangat valid dan sangat layak digunakan dalam proses pembelajaran karena dapat memotivasi siswa belajar (Jayusman et al., 2017). Sedangkan, pengembangan multimedia berbasis Power Point disertai Games kuis Course Maze pada materi sistem ekskresi memiliki hasil dengan kriteria valid dan praktis diterapkan pada proses pembelajaran (Monemi et al., 2017). Penelitian lain menunjukkan bahwa pengembangan program Microsoft Office Power Point berbasis Android dengan menggunakan pendekatan kontekstual sangat efektif diterapkan dalam proses pembelajaran serta dapat meningkatkan hasil belajar siswa (Bagus \& Khuzaini, 2019). Berdasarkan paparan sebelumnya, dipandang perlu mengembangkan media Power Point untuk meningkatkan minat belajar siswa khususnya pada materi siklus air muatan IPA. pengembangan media Power Point ini akan membuat siswa lebih tertarik mempelajari pokok bahasan Siklus Air pada muatan IPA yang dikemas dalam slide Power Point. Tujuan penelitian ini untuk mengembangkan Media Power Point Berbasis Pendekatan Kontekstual pada Materi Siklus Air Muatan IPA Kelas V Sekolah Dasar. Sehingga siswa akan mendapatkan pengalaman belajar yang lebih bervariasi dan bermakna.

\section{Metode}

Penelitian ini merupakan jenis penelitian pengembangan. Dalam penelitian ini dikembangkan media Power Point berbasis pendekatan kontekstual pada materi siklus air muatan IPA yang dilaksanakan pada siswa kelas VA di SD Negeri 1 Baturiti, menggunakan model pengembangan Hannafin and Peck yang terdiri dari tahap penilaian kebutuhan, tahap desain dan tahap pengembangan dan implementasi

Tahap pertama pada model pengembangan Hannafin and Peck adalah penilaian kebutuhan. Tahap analisis kebutuhan dimaksudkan untuk mengitentifikasi kebutuhankebutuhan dalam pengembangan. Kebutuhan-kebutuhan yang dimaksud seperti permasalahan pembelajaran yang terjadi, proses pembelajaran, kesediaan peralatan pendukung produk dan sasaran produk. Informasi tersebut dapat diperoleh melaui wawancara, observasi, dan diskusi. Hasil dari analisis penilaian kebutuhan akan digunakan pada tahap selanjutnya. Kemudian dilanjutkan dengan tahap kedua yaitu tahap desain. Pada tahap desain yang dilakukan adalah mengolah hasil analisis penilaian kebutuhan dalam bentuk dokumen yang dapat digunakan dalam menentukan desain produk. Adapun dokumen yang dihasilkan adalah kerangka media, tampilan media dan menetapkan desain media. Tahap ketiga dari model pengembangan Hannafin and Peck adalah pengembangan dan implementasi. Pada tahap ini dilakukan kegiatan mengembangkan media. Setelah itu media pembelajaran yang sudah dikembangkan kemudian dievaluasi, sehingga media yang dikembangkan sesuai dengan kebutuhan dan dapat diimplementasikan dalam pembelajaran secara nyata.

Metode pengumpulan data dalam penelitian ini dikumpulkan melalui pelaksanaan evaluasi formatif. Data-data yang telah terkumpul, kemudian dikelompokkan menurut sifatnya menjadi dua yaitu data kualitatif dan kuantitatif. Metode yang digunakan untuk mengumpulan data yaitu dengan kuesioner/angket, observasi, wawancara, dan pencatatan dokumen. Pengembangan media Power Point berbasis pendekatan kontekstual ini diharapkan dapat memiliki tingkat kelayakan yang tinggi sehingga layak digunakan dalam proses pembelajaran. Untuk mengetahui kelayakan dari media Power Point maka dilakukan uji coba produk yang terdiri dari beberapa tahapan, yaitu: review oleh ahli isi pembelajaran, review oleh ahli desain pembelajaran, review oleh ahli media pembelajaran, dan uji coba perorangan. 
Dalam penelitian pengembangan ini digunakan dua teknik analisis data, yaitu teknik analisis deskriptif kualiatif, dan analisis deskriptif kuantitatif. Teknik analisis deskriptif kualitatif dilakukan dengan mengelompokkan informasi-informasi dari data kualitatif yang berupa masukan, tanggapan, kritik, dan saran perbaikan yang terdapat pada angket dan hasil wawancara. Hasil analisis data kemudian digunakan untuk merevisi produk yang dikembangkan. Teknik analisis dskriptif kuantitatif digunakan untuk mengolah data yang diperoleh melalui angket dalam bentuk deskriptif persentase. Data skor yang diperoleh dari para ahli dalam penelitian ini dianalisis menggunakan skala likert yang dimodifikasi. Subjek uji coba perorangan pada penelitian ini menggunakan 3 siswa, untuk menghitung persentase keseluruhan subjek perlu dicari rata-rata dari seluruh skor dengan cara menjumlahkan seluruh persentase responden kemudian dibagi dengan jumlah responden. Selanjutnya hasil yang diperoleh dikriteriakan menggunakan konversi tingkat pencapaian skala lima kelayakan media.

\section{Hasil dan Pembahasan Hasil Penelitian}

Penelitian ini dilakukan untuk mengetahui rancang bangun dan validitas media Power Point berbasis pendekatan kontekstual. Pengembangan media Power Point berbasis pendekatan kontekstual ini dikembangkan menggunakan model Hannafin and Peck. Model Hannafin and Peck adalah model desain pengajaran yang terdiri dari tiga tahapan. Adapun tiga tahapan dari model pengembangan Hannafin and Peck, yaitu: (1) tahap analisis kebutuhan (Need Assesment), (2) tahap mendesain produk (design), dan (3) tahap pengembangan dan implementasi (development and implementation) (Tegeh et al., 2014). Dalam model ini, penilaian dan pengulangan perlu dijalankan dalam setiap fase. Model ini adalah model desain pembelajaran yang berorientasi produk.

Tahap pertama pada model pengembangan Hannafin and Peck adalah penilaian kebutuhan. Pada tahap ini dilakukan analisis karakteristik siswa, analisis konten, analisis lingkungan dan fasilitas sekolah. Metode yang digunakan untuk mengetahui karakteristik siswa adalah kuesioner. Berdasarkan hasil analisis dari penyebaran kuesioner kepada siswa secara online, dapat disimpulkan bahwa karakteristik siswa kelas VA di SD Negeri 1 Baturiti merupakan siswa yang senang belajar menggunakan media pembelajaran audio visual dengan animasi dan gambar yang menarik. Hal tersebut dapat dilihat dari kuesioner yang disebarkan kepada siswa bahwa dari 13 siswa keseluruhan menjawab senang belajar menggunakan media pembelajaran audio visual dengan animasi dan gambar yang menarik. Pada tahap analisis konten dinggunakan metode wawancara dengan guru kelas VA di SD Negeri 1 Baturiti, diperoleh hasil materi yang akan dicantumkan adalah materi tentang siklus air pada mata pelajaran IPA. Kemudian pada analisis lingkungan menunjukkan bahwa sangat cocok dikembangkan media Power Point. Karena, pada proses obeservasi lingkungan menunjukkan bahwa sekolah belum memiliki media Power Point yang dapat mendukung dan mengaktifkan siswa saat belajar yang disesuaikan juga dengan kondisi saat ini

Kemudian dilanjutkan dengan tahap kedua yaitu tahap desain. Adapun dokumen yang dihasilkan adalah kerangka media (Flowchart dan Storyboard), tampilan media, menetapkan desain media, menyusun instrumen dan RPP. Tahap ketiga dari model pengembangan Hannafin and Peck adalah pengembangan dan implementasi. Pada tahap ini dilakukan kegiatan mengembangkan media. Setelah itu media pembelajaran yang sudah dikembangkan kemudian dievaluasi, sehingga media yang dikembangkan sesuai dengan kebutuhan dan dapat diimplementasikan dalam pembelajaran secara nyata. Setelah media Power Point dikembangkan dilakukan evaluasi melalui uji coba tahap pertama yang dilakukan oleh ahli isi pembelajaran dengan menggunakan instrument kuesioner. Adapun hasil review dari ahli isi 
pembelajaran menunjukkan presentase sebesar 90,00\% dengan kualifikasi sangat baik, sehingga tidak perlu direvisi. Berdasarkan hasil uji ahli isi pembelajaran tersebut maka dapat disimpulkan bahwa media Power Point yang dikembangkan layak untuk digunakan. Setelah dilakukan review ahli isi pembelajaran dilanjutkan dengan review ahli desain pembelajaran yang menunjukkan hasil presentase sebesar 90,38\% dengan kualifikasi sangat baik, sehingga tidak perlu direvisi. Berdasarkan hasil uji ahli desain pembelajaran tersebut maka dapat disimpulkan bahwa media Power Point yang dikembangkan layak untuk digunakan.

Selanjutnya pada tahap ketiga dilakukan review oleh ahli media pembelajaran. Adapun hasil review dari ahli media pembelajaran menunjukkan presentase sebesar $88,33 \%$ dengan kualifikasi baik, sehingga perlu sedikit direvisi. Berdasarkan hasil uji ahli media pembelajaran tersebut maka dapat disimpulkan bahwa media Power Point yang dikembangkan layak untuk digunakan akan tetapi tidak menutup kemungkinan untuk dilakukan evaluasi kembali. Pada tahap keempat dilakukan uji coba perorangan terhadap kelayakan produk media Power Point yang dilakukan oleh tiga siswa kelas VA di SD Negeri 1 Baturiti. Ketiga siswa tersebut terdiri atas prestasi belajar rendah, sedang dan tinggi. Adapun hasil uji coba perorangan menunjukkan presentase sebesar 92,50\% dengan kualifikasi sangat baik, sehingga tidak perlu direvisi. Berdasarkan hasil uji coba perorangan tersebut maka dapat disimpulkan bahwa media Power Point yang dikembangkan layak untuk digunakan. Adapun data yang diperoleh akan dipaparkan secara lebih rinci pada Tabel 1.

Tabel 1. Persentase Hasil Validitas Pengembangan Media Power Point

\begin{tabular}{clll}
\hline No & \multicolumn{1}{c}{ Subjek Uji Coba } & Hasil Validitas & Keterangan \\
\hline 1 & Uji Ahli Isi Pembelajaran & $90,00 \%$ & Sangat Baik \\
2 & Uji Ahli Desain Pembelajaran & $90,38 \%$ & Sangat Baik \\
3 & Uji Ahli Media Pembelajaran & $88,33 \%$ & Baik \\
4 & Uji Coba Perorangan & $92,50 \%$ & Sangat Baik \\
\hline
\end{tabular}

Berdasarkan Tabel 3 menunjukkan bahwa persentase hasil validitas pengembangan media Power Point menurut subjek uji coba ahli isi pembelajaran, ahli desain pembelajaran, ahli media pembelajaran dan uji coba perorangan secara berturut-turut sebesar $90,00 \%$, 90,38\%, 88,33\%, dan 92,50\%. Hasil akhir pengembangan media Power Point ini dapat dilihat pada Gambar 1 dan Gambar 2.

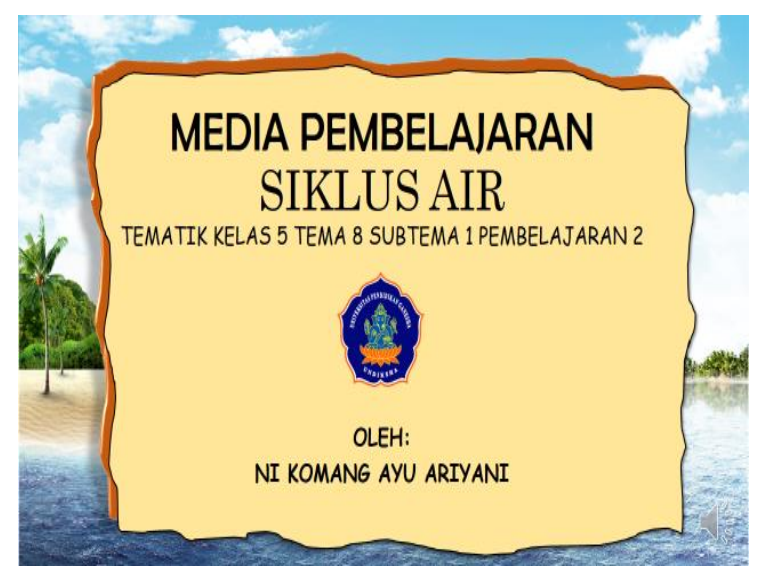

Gambar 1. Tampilan Awal Media Power Point

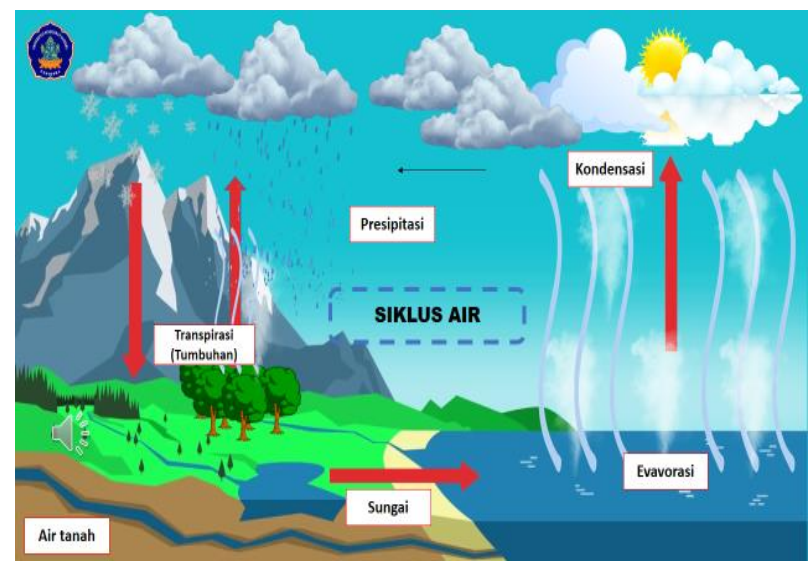

Gambar 2. Tampilan Isi Media Power Point 


\section{Pembahasan Hasil Penelitian}

Penelitian pengembangan ini produk yang dihasilkan adalah media Power Point berbasis pendekatan kontekstual untuk kelas V SD Negeri 1 Baturiti. Media ini dikembangkan untuk memfasilitasi siswa untuk menciptakan suasana belajar yang menarik dan lebih berakna (Sumerta \& Sudana, 2019). Media yang dikembangkan memuat tentang materi siklus air muatan IPA. Media disertai dengan gambar-gambar, animasi, dan juga video yang dapat mendukung pembelajaran siswa, sehingga mempermudah siswa memahami materi saat belajar (Wuryanti \& Kartowagiran, 2016). Media Power Point berbasis pendekatan kontekstual ini telah melewati beberapa tahap uji coba dan perbaikan dalam pengembangannya. Uji coba yang dilakukan adalah review dari ahli isi pembelajaran, ahli desain pembelajaran, ahli media pembelajaran, dan uji coba perorangan. (Suartama, 2016). Setiawan (2019) menjelaskan pembelajaran IPA di Sekolah Dasar dapat bertujuan untuk memberikan pengalaman kepada siswa dalam merencanakan dan melakukan kerja ilmiah untuk membentuk sikap ilmiah, meningkatkan kesadaran guna memelihara dan melestarikan lingkungan serta sumber daya alam (Iswanto et al., 2018; Lohr et al., 2021). Dengan demikian media Power Point yang dikembangkan dinyatakan sudah valid karena dapat digunakan untuk siswa dalam kegiatan pembelajaran khususnya pada pembelajaran siklus air muatan IPA serta dapat memberikan pembelajaran yang bermakna bagi siswa.

Pada aspek desain, media Power Point yang dikombinasikan dengan teks, gambar, animasi, dan suara/audio dapat menarik perhatian siswa sehingga siswa dapat lebih memahami materi pembelajaran. Dengan demikian dapat dikatakan bahwa media Power Point yang dikembangkan sudah valid sehingga dapat digunakan untuk siswa dalam kegiatan pembelajaran khususnya pada pembelajaran siklus air muatan IPA. Strategi pembelajaran perlu disusun sedemikian rupa agar dapat membantu proses belajar mengajar. Strategi yang dapat digunakan yaitu dengan menggunakan pendekatan kontekstual dalam pembelajaran. Pendekatan kontekstual merupakan konsep belajar yang membantu guru mengaitkan antara materi yang diajarkannya dengan situasi dunia nyata siswa, Melalui Pendekatan kontekstual, siswa mampu mengaitkan makna pada mata pelajaran akademik mereka dengan cara yang tepat (Sulastri, 2016). Sejalan dengan hasil dan pendapat tersebut pendekatan kontekstual dapat membantu penyampaian materi dalam pembelajaran agar proses pembelajaran berjalan dengan baik. Ketertarikan siswa dalam belajar dapat dilihat dari adanya perasaan tertarik dan senang untuk belajar, adanya partisipasi aktif, adanya kecenderungan untuk memperhatikan dan konsentrasi yang besar, dimilikinya perasaan positif dan kemauan belajar yang terus meningkat, adanya kenyamanan saat belajar (Ricardo \& Meilani, 2017). Dilihat dari komentar dan saran oleh subjek uji coba perorangan yang diberikan oleh responden/siswa, media Power Point mendapatkan respon yang positif. Media pembelajaran Power Point dapat menjadi alternative dalam pembelajaran di Sekolah Dasar karena penggunaannya yang relatif mudah (Agustiana \& Rusmana, 2018).

Temuan dari penelitian yang sudah ada sebelumnya mendukung penelitian ini yaitu media Power Point IPA di kelas IV SD dapat meningkatkan ketertarikan siswa pada media pembelajaran (Wijayanti \& Christian Relmasira, 2019). Hasil penelitian dari Irfan et al. (2019) menunjukkan penggunaan media pembelajaran IPA berbasis Power Point di SD dapat menarik perhatian dan motivasi siswa dalam menerima pembelajaran (Hendra Anggryawan, 2018; Irfan et al., 2019). Multimedia Power Point dapat memotivasi dan menarik perhatian siswa serta dapat membantu guru dalam penyediaan sumber belajar (Bagus \& Khuzaini, 2019; Iswanto et al., 2018). Hasil penelitian dari Monemi et al. (2017) menunjukkan bahwa media Power Point yang disertai games kuis course maze memiliki kriteria yang valid dan praktis sehingga dapat membantu peserta didik dalam memahami materi dan dapat memotivasi peserta didik dalam belajar (Monemi et al., 2017). 
Dikembangkannya media Power Point berbasis Pendekatan Kontekstual pada materi siklus air kelas V SD ini dapat membantu siswa memecahkan masalah-masalah belajar sehingga siswa dapat memahami materi, meningkatkan ketertarikan siswa dalam belajar, serta dapat memotivasi siswa. Berdasarkan penilaian dari para ahli dan uji coba perorangan, media Power Point layak untuk digunakan dalam proses pembelajaran.

\section{Simpulan}

Media Power Point Berbasis Pendekatan Kontekstual pada Materi Siklus Air Muatan IPA Kelas V Sekolah Dasar memperoleh kualifikasi sangat baik dari ahli isi pembelajaran, ahli desain pembelajaran, uji coba perorangan, dan memperoleh kualifikasi baik dari ahli media pembelajaran. Sehingga layak digunakan dalam proses pembelajaran karena dapat menarik minat belajar siswa. Saran yang dapat dikemukakan yaitu hasil penelitian ini dapat dijadikan sebagai referensi untuk menambah wawasan pembaca, sebagai referensi penelitian yang relevan dan dapat dikembangkan lebih lanjut ke tahap uji efektivitas.

\section{Daftar Rujukan}

Agustiana, L., \& Rusmana, I. M. (2018). Pemanfaatan Microsoft Power Point sebagai Alternatif Media. Prosiding Seminar Dan Diskusi Nasional Pendidikan Dasar, 374379. http://journal.unj.ac.id/unj/index.php/psdpd/article/view/10164.

Ariyanto, M. (2018). Peningkatan Hasil Belajar Ipa Materi Kenampakan Rupa Bumi Menggunakan Model Scramble. Profesi Pendidikan Dasar, 3(2), 133. https://doi.org/10.23917/ppd.v3i2.3844.

Azura, A. R., Kamariyah, N., \& Taufiq, M. (2019). Pengembangan Model Pembelajaran Discovery Learning Terhadap Hasil Belajar Siswa Pada Mata Pelajaran IPA Dengan Materi Perubahan Wujud Benda Kelas V Di Sd Al-Islah Surabaya. Journal of Natural Science Education Research, 1(2), 171-180. https://doi.org/http://journal.trunojoyo.ac.id/nser/article/view/5187/3505.

Bagus, T., \& Khuzaini, N. (2019). Pengembangan Program Microsoft Office Power Point Berbasis Android untuk Meningkatkan Hasil Belajar. Jurnal Pendidikan Matematika, 1-14. https://doi.org/http://eprints.mercubuana-yogya.ac.id/7099/.

Budiman, H. (2017). Peran Teknologi Informasi Dan Komunikasi Dalam Pendidikan. AlTadzkiyyah: Jurnal Pendidikan $\quad$ Islam, $3(1), \quad 31$. https://doi.org/10.24042/atjpi.v8i1.2095.

Busyaeri, A., Udin, T., \& Zaenudin, A. (2016). Pengaruh Penggunaan Video Pembelajaran Terhadap Peningkatan Hasil Belajar Mapel Ipa Di Min Kroya Cirebon. Jurnal Pendidikan Guru MI, 3(1), 116-137. https://doi.org/10.24235/al.ibtida.snj.v3i1.584.

Christopher, A. E., Waluyanto, H. D., \& Wahyudi, A. T. (2019). Perancangan Board Game Pembelajaran Toleransi Terhadap Perbedaan Pada Pelajaran Ppkn. Jurnal DKV Adiwarna, 2(15), 1-9. https://doi.org/http://publication.petra.ac.id/index.php/dkv/article/view/9733.

Dewi, R. K., Wardani, S., Wijayati, N., \& Sumarni, W. (2019). Demand of ICT-Based Chemistry Learning Media in the Disruptive Era. International Journal of Evaluation and Research in Education, 8(2), 265-270. https://doi.org/10.11591/ijere.v8i2.17107.

Hendra Anggryawan, I. (2018). Pengaruh Fasilitas Belajar dan Motivasi Belajar Terhadap Hasil Belajar Siswa Pada Mata Pelajaran Ekonomi. Jurnal Pendidikan Ekonomi (JUPE), 2(1), 19-28. https://doi.org/10.26740/jupe.v7n3.p71-75. 
Irfan, Muhiddin, \& Ristiana, E. (2019). Pengembangan Media Pembelajaran IPA Berbasis Powerpoint di Sekolah Dasar. Indonesian Journal of Primary Education, 3(2), 16-27. https://doi.org/https://ejournal.upi.edu/ index.php/IJPE/article/view/21765.

Iswanto, E., Suharmono, R., \& Hidayat, S. (2018). Pengaruh Penggunaan Media Pembelajaran Berbasis Powerpoint Dan Buku Teks Terhadap Hasil Belajar Ilmu Pengetahuan Alam (Ipa) Materi Tata Surya Siswa Kelas Vi Semester Ganjil Tahun Pelajaran. Jurnal of Education Technologi and Innovation (JETI), 1(2), 7-20. https://doi.org/https://doi.org/10.31537/jeti.v1i2.

Jayusman, I., Gurdjita, G., \& Shavab, O. A. K. (2017). Pengembangan Media Pembelajaran Multi Media Power Point Pada Mata Kuliah Sejarah Asia Timur. Jurnal $\begin{array}{llll}\text { Candrasangkala Pendidikan } & \text { Sejarah, } & 3(1),\end{array}$ https://doi.org/10.30870/candrasangkala.v3i1.2886.

Kharisma, G. I., \& Arvianto, F. (2019). Pengembangan aplikasi android berbentuk education games berbasis budaya lokal untuk keterampilan membaca permulaan bagi siswa kelas 1 SD/MI. Premiere Educandum : Jurnal Pendidikan Dasar Dan Pembelajaran, 9(2), 203. https://doi.org/10.25273/pe.v9i2.5234.

Kurniati, \& Perdana, D. C. (2018). Kajian Teori Mengenai Multimedia Interaktif Power Point Berbasis Konteks Dan Pemahaman Matematis. Jurnal Universitas Ibn Khaldun, Bogor, 1, 382-388. https://doi.org/http://pkm.uika- bogor.ac.id/index. $\mathrm{php} / \mathrm{SNTP} /$ article/view/282.

Kuswanto, J., \& Radiansah, F. (2018). Media Pembelajaran Berbasis Android Pada Mata Pelajaran Sistem Operasi Jaringan Kelas XI. Jurnal Media Infotama, 14(01), 129. https://doi.org/https://jurnal.unived.ac.id /index.php/jmi/article/view/467.

Lohr, A., Stadler, M., Schultz-Pernice, F., Chernikova, O., Sailer, M., Fischer, F., \& Sailer, M. (2021). On powerpointers, clickerers, and digital pros: Investigating the initiation of digital learning activities by teachers in higher education. Computers in Human Behavior, 119. https://doi.org/https://doi.org/10.1016/j.chb.2021.106715.

Monemi, R., Lufri, \& Leilani, I. (2017). Pengembangan Multimedia Interaktif Berbasis Power Point Disertai Games Kuis Course Maze Pada Materi Sistem Ekskresi Untuk Peserta Didik Kelas Viii Smp Developing Interactive Multimedia Based on Power Point With Course Maze Games Kuis About Excretion Syste. Journal Biosains, 1(2), 252-260.

https://doi.org/http://ejournal.unp.ac.id/students/index.php/bio/issue/download/355/56

Muhson, A. (2010). Pengembangan Media Pembelajaran Berbasis Teknologi Informasi. Jurnal Pendidikan Akuntansi Indonesia, 8(2). https://doi.org/10.21831/jpai.v8i2.949.

Nurhidayati, N., Asrori, I., Ahsanuddin, M., \& Dariyadi, M. W. (2019). Pembuatan Media Pembelajaran Berbasis Powerpoint Dan Pemanfaatan Aplikasi Android Untuk Guru Bahasa Arab. Jurnal KARINOV, 2(3), 181. https://doi.org/10.17977/um045v2i3p181184.

Pakpahan, R., \& Fitriani, Y. (2020). Analisa Pemafaatan Teknologi Informasi Dalam Pemeblajaran Jarak Jauh Di Tengah Pandemi Virus Corona Covid-19. JISAMAR (Journal of Information System, Applied, Management, Accounting and Researh), 4(2), 30-36. http://journal.stmikjayakarta.ac.id/index.php/jisamar/article/view/181.

Ricardo, \& Meilani, R. I. (2017). Impak Minat dan Motivasi Belajar Terhadap Hasil Belajar Siswa. Jurnal Pendidikan Manajemen Perkantoran, 2(2), 79. https://doi.org/10.17509/jpm.v2i2.8108.

Seruni, R., Munawaoh, S., Kurniadewi, F., \& Nurjayadi, M. (2019). Pengembangan Modul Elektronik (E-Module) Biokimia Pada Materi Metabolisme Lipid Menggunakan Flip 
Pdf Professional. JTK (Jurnal Tadris Kimiya), 4(1), 48-56. https://doi.org/10.15575/jtk.v4i1.4672.

Setiawan, A. R. (2019). Penyusunan Program Pembelajaran Biologi Berorientasi Literasi Saintifik. 2(1), 109-116. https://doi.org/10.31226/osf.io/etg5n.

Sholiha, A. (2017). Efektivitas Pembelajaran Geografi Pokok Bahasan Siklus Air dengan Menggunakan Media Komik Strip Pada Siswa Kelas X IPS Man Purwodadi. Fakultas Ilmu Sosial, Universitas Negeri Malang. https://doi.org/https://lib.unnes.ac.id/31728/1/3201412036.

Suartama, I. K. (2016). Evaluasi dan Kriteria Kualitas Multimedia Pembeajaran (Issue January 2016). Universitas Pendidikan Ganesha.

Sulastri, A. (2016). Penerapan Pendekatan Kontekstual Dalam Pembelajaran Matematika Untuk Meningkatkan Pemahaman Konsep Matematis Siswa Sekolah Dasar. Jurnal Pendidikan Guru Sekolah Dasar, 1(1), 156-170. https://doi.org/10.17509/jpgsd.v1i1.9068.

Sumerta, I. W., \& Sudana, D. N. (2019). Pengaruh Model Pembelajaran Kooperatif Tipe Snowball Throwing Berbantuan Lagu Daerah Terhadap Hasil Belajar Ipa. Jurnal Ilmiah Pendidikan Profesi Guru, 2(1). https://doi.org/10.23887/jippg.v2i1.18085.

Sunarni, S. (2016). Pengembangan Media Pembelajaran Power Point. Jurnal Penelitian Dan $\begin{array}{llll}\text { Pendidikan } & \text { IPS } & \text { (JPPI), } & \text { 363-372. }\end{array}$ https://doi.org/http://ejournal.unikama.ac.id/index.php/JPPI.

Supriyono. (2018). Pentingnya Media Pembelajaran Untuk Meningkatkan Minat Belajar Siswa SD. Edustream: Jurnal Pendidikan Dasar, II(1), 43-48. https://journal.unesa.ac.id/index.php/jpd/article/view/6262/3180.

Suwasono. (2013). Pengembangan E-Modul Online Elektronika Analog Pada Pendidikan Jarak Jauh. Teknologi Dan Kejuruan, 36(1), 51-62. https://doi.org/10.17977/tk.v36i1.4070.

Tegeh, I. M., Jampel, I. N., \& Pudjawan, K. (2014). Model Penelitian Pengembangan. Graha Ilmu.

Ulya, I. F., \& Irawati, R. (2016). Peningkatan Kemampuan Koneksi Matematis Dan Motivasi Belajar Siswa Menggunakan Pendekatan Kontekstual. Jurnal Pena Ilmiah, 1(1), 121130. https://doi.org/10.23819/pi.v1i1.2940.

Wijayanti, W., \& Christian Relmasira, S. (2019). Pengembangan Media PowerPoint IPA Untuk Siswa Kelas IV SD Negeri Samirono. Jurnal Penelitian Dan Pengembangan Pendidikan, 3(2), 77. https://doi.org/10.23887/jppp.v3i2.17381.

Wuryanti, U., \& Kartowagiran, B. (2016). Pengembangan Media Video Animasi Untuk Meningkatkan Motivasi Belajar Dan Karakter Kerja Keras Siswa Sekolah Dasar. Jurnal Pendidikan Karakter, 6(2), 232-245. https://doi.org/10.21831/jpk.v6i2.12055.

Yusup, M., Aini, Q., \& Pertiwi, K. D. (2016). Media Audio Visual Menggunakan Videoscribe Sebagai Penyajian Informasi Pembelajaran Pada Kelas Sistem Operasi. Technomedia Journal, 1(1), 126-138. https://doi.org/10.33050/tmj.v1i1.8. 